\title{
Positron Emission Tomography in Psychiatry: New Sights, New Insights
}

\author{
Shitij Kapur, MD \\ PET Center of the Clarke Institute of Psychiatry in Toronto Ontario \\ Sylvain Houle, MD, PhD, FRCP (C) \\ PET Center of the The Clarke Institute of Psychiatry, Toronto, Ontario \\ Gregory M. Brown, MD, PhD, FRCP (C) \\ PET Center of the The Clarke Institute of Psychiatry, Toronto, Ontario
}

Follow this and additional works at: https://jdc.jefferson.edu/jeffjpsychiatry

Part of the Psychiatry Commons

Let us know how access to this document benefits you

\section{Recommended Citation}

Kapur, MD, Shitij; Houle, MD, PhD, FRCP (C), Sylvain; and Brown, MD, PhD, FRCP (C), Gregory M. (1994)

"Positron Emission Tomography in Psychiatry: New Sights, New Insights," Jefferson Journal of Psychiatry.

Vol. 12 : Iss. 1 , Article 10.

DOI: https://doi.org/10.29046/JJP.012.1.007

Available at: https://jdc.jefferson.edu/jeffjpsychiatry/vol12/iss1/10

This Article is brought to you for free and open access by the Jefferson Digital Commons. The Jefferson Digital Commons is a service of Thomas Jefferson University's Center for Teaching and Learning (CTL). The Commons is a showcase for Jefferson books and journals, peer-reviewed scholarly publications, unique historical collections from the University archives, and teaching tools. The Jefferson Digital Commons allows researchers and interested readers anywhere in the world to learn about and keep up to date with Jefferson scholarship. This article has been accepted for inclusion in Jefferson Journal of Psychiatry by an authorized administrator of the Jefferson Digital Commons. For more information, please contact: JeffersonDigitalCommons@jefferson.edu. 


\title{
Positron Emission Tomography In Psychiatry: New Sights, New Insights
}

\author{
Shitij Kapur, MD \\ Sylvain Houle, MD, PhD, FRCP(C) \\ Gregory M Brown, MD, PhD, FRCP(C)
}

\begin{abstract}
Positron Emission Tomography (PET) is a new tool with which to explore the neurobiological basis of psychiatric illness. PET permits in-vivo measurement of regional cerebral blood flow, regional glucose metabolism, as well as information about neurochemicals and their receptors. Since regional cerebral blood flow and glucose metabolism reflect ongoing neuronal activity, the neural bases of different cognitive processes and emotional states can be discerned using PET. Findings from recent studies in schizophrenia, affective disorders, obsessive-compulsive disorders, anxiety disorders, and dementia are reviewed with a special emphasis on how these findings may be useful in developing a more comprehensive framework for understanding the neurobiological basis of psychiatric disorders. The relationship between PET and other brain imaging modalities, the imminent improvements in PET technology, as well as future directions of research are discussed.
\end{abstract}

\section{INTRODUCTION}

Neurobiological factors are important determinants of psychiatric illness. However, how these neurobiological factors lead to the observed psychiatric symptoms is far from clear. Investigations using indirect (e.g. plasma, urine and cerebrospinal fluid neurochemistry, receptor expression in peripheral sites) and direct indices (e.g. CT scans, MRI scans, surface electrophysiological recordings, neuroendocrine challenges) have confirmed the association between neurobiological factors and psychiatric illnesses. However, in the absence of a comprehensive framework for understanding behavior and emotion in the context of brain function, these findings remain isolated empirical facts. The challenge now is to unite these facts into a useful theoretical framework - one which will permit a pathophysiological understanding of psychiatric illness, and a rational basis for the treatment of these disorders. Herein lies the promise of PET.

PET offers the opportunity to develop a unified theory relating emotions and behavior to neurophysiological and neurochemical events in a neuroanatomical

Shitij Kapur, M.D. is a research fellow at the PET Center of The Clarke Institute of Psychiatry in Toronto, Ontario, where Sylvain Houle, M.D., Ph.D., is the Director and an assistant professer of psychiatry and radiology and where Gregory M. Brown, M.D., Ph.D., is the Director of Research and a professor of psychiatry and physiology. 
context. To illustrate, it is known that certain focal lesions (e.g. left frontal strokes), or certain systemic neurochemical alterations (e.g. sympathomimetic withdrawal), or profound psychosocial stress (e.g. death of a spouse) may all lead to a depressive syndrome. Furthermore, all the above cases may respond to treatment with a serotonin-specific reuptake inhibitor (SSRI) antidepressant. PET offers, at least in principle, the opportunity to unify these isolated facts. By elucidating the network of brain regions subserving mood (1), it may help us to understand why left frontal strokes are particularly crucial in inducing depressive symptoms. By specifying how cognition and stress influence this network of regions, one may understand how situational factors may induce depression. By unraveling the role of neurotransmitters in the modulation of this 'mood network', one may understand how sympathomimetic withdrawal induces depression and SSRIs treat it (2).

In this article, we review PET as it is relevant to the field of psychiatry. The first section will provide the readers with a glimpse into the physical principles and the instrumentation as relevant for the interpretation of PET studies. The second section will describe the physiological parameters that can be measured using PET. The third section reviews how PET studies have contributed to our understanding of various psychiatric illnesses. Finally, we outline the relationship of PET to other imaging modalities and the future technical and experimental improvements which may be important from the perspective of psychiatry.

\section{HOW IS PET SCANNING DONE?}

PET scanning depends upon the visualization of radiolabelled tracers introduced into the body. There are two major components to a PET program-radiochemistry and imaging. The account below is intentionally brief-for a more thorough account the reader is referred to more comprehensive sources (3-5).

\section{Radiochemistry}

The tracers used for PET are specially synthesized molecules which contain a positron-emitting isotope. Positron-emitting isotopes of common elements like carbon, oxygen, nitrogen and fluoride $(\mathrm{C}, \mathrm{O}, \mathrm{N}$ and $\mathrm{F}$ respectively) are preferred since these elements naturally occur in a wide variety of biologically relevant molecules. These isotopes have short half-lives ( ${ }^{11} \mathrm{C}-20$ minutes, ${ }^{15} \mathrm{O}-2$ minutes, ${ }^{18} \mathrm{~F}-110$ minutes) which necessitates a cyclotron facility, which generates the isotopes, either on-site or near the scanning facility. Once the isotope is produced, it is incorporated into the molecule of interest (e.g. ${ }^{15} \mathrm{O}$ is incorporated in water for blood flow studies, and may also be inhaled in a gaseous form; ${ }^{18} \mathrm{~F}$ is attached to deoxyglucose for glucose metabolism studies; ${ }^{11} \mathrm{C}$ is incorporated into raclopride, resulting in ${ }^{11} \mathrm{C}$-raclopride, which binds to dopamine $\mathrm{D}_{2}$ receptors). This process of incorporating the isotope into the tracer agent is particularly demanding since high levels of chemical purity and specific-activity have to be assured in a short period of time as the isotopes are rapidly decaying. 
Imaging

The scanning is done with the subject lying horizontally. The tracer is administered via an injection or, if gaseous, via inhalation. The amount of radioactivity administered, the time of administration, and the duration of uptake all vary depending upon the exact nature of the tracer and the purpose of the study. As the tracer undergoes rapid decay it emits positrons. The positron, a positively charged particle, travels a short distance (less than $3 \mathrm{~mm}$ ) in the tissue and then combines with an electron. This combination leads to the generation of two $511 \mathrm{keV}$ photons which travel in diametrically opposite directions. The ring of high-sensitivity detectors surrounding the head (the camera) detects these photons. As the two photons emitted from a single positron-electron combination, traveling in diametrically opposite directions, strike two diametrically opposite detectors, a 'coincidence event' is recorded. The coincidence event is the building block of the PET image. Thousands of such coincidence events are recorded during each scan and are used to reconstruct the image of the tracer distribution in the head. This reconstructed image constitutes the PET scan. With knowledge of the amount of tracer injected, and its distribution within the different body compartments, the acquired image can be converted into quantitative physiological data. For example, a PET image obtained with fluorodeoxyglucose as a tracer can be converted into a metabolic image which estimates regional brain metabolism in terms of milligrams of glucose metabolized per $100 \mathrm{gm}$ of tissue per minute in different parts of the brain. Thus, PET not only images the functioning of the brain, it also measures it (6).

\section{WHAT CAN BE MEASURED WITH PET?}

Studies done with PET in the last decade can be broadly divided into three types: cerebral blood flow studies; glucose metabolism studies and neurochemical studies.

\section{Cerebral Blood Flow (rCBF) Studies}

The tracer used for $\mathrm{rCBF}$ imaging is usually water containing ${ }^{15} \mathrm{O}$, injected intravenously. The scanning begins immediately after the injection and lasts $60-120$ seconds. ${ }^{15} \mathrm{O}$ has a short half-life and the tracer decays almost completely within 10 minutes of injection. This allows the procedure to be repeated up to 12 times in a single session (7). rCBF closely reflects regional neuronal activity (8), and hence, by repeating scans while the subject is engaged in different tasks, and by comparing the brain regions activated in the different tasks, one can discern the brain regions involved in specific cognitive operations (9-11). In a prototypical application of this strategy, Petersen and colleagues (10) scanned subjects during three different cognitive tasks-passive viewing of presented words, oral repetition of presented words, and generation of verbs associated with the presented words. By comparing the rCBF scans obtained during the different tasks they were able to delineate areas 
of the brain which were involved in the visual recognition of words, in the production of speech, and in the act of semantic association (10).

\section{Cerebral Glucose Metabolism (rCMGlu) Studies}

The tracer, ${ }^{18} \mathrm{~F}$-fluoro-deoxyglucose (FDG), is taken up by the tissues in a manner similar to naturally occurring glucose, but once inside the cell, FDG does not undergo further metabolism and is trapped (12). The tracer is injected intravenously, and is taken up by the brain over the next 45-60 minutes. Tracer 'uptake' is proportional to the rate of glucose metabolism in a given region and reaches equilibrium in $45-60$ minutes. Once equilibrium is reached the scanning begins and may require 15 to 30 minutes to acquire a high-resolution image (12). An important difference between a rCBF and a rCMGlu PET scan is that the former reflects brain activity over 60-90 seconds whereas the latter reflects activity over 45-60 minutes. In addition, ${ }^{18} \mathrm{~F}$ has a much longer half-life, and therefore the FDG scans cannot be repeated within a single session. Since ${ }^{15} \mathrm{O}$-water scans reflect brain activity over briefer epochs and can be repeated multiple times within a session, these scans are the preferred measure for comparing neural activity in different cognitive, emotional or sensori-motor tasks (13).

\section{Neurochemical Studies}

These studies use specific ligands to determine the concentration and distribution of receptors, neurotransmitters, and other neurochemicals within the brain $(14,15)$. For example, raclopride, an antipsychotic which binds to the dopamine $\mathrm{D}_{2}$ receptor is frequently used. ${ }^{11} \mathrm{C}$ labeled raclopride can be used to visualize the level of $\mathrm{D}_{2}$ dopamine receptors in the human striatum, and to compare the level of these receptors in the striatum of patients with schizophrenia to those of normal controls (16-18). These studies involve the synthesis of a positron-emitter $\left({ }^{11} \mathrm{C}\right.$ or ${ }^{18} \mathrm{~F}$ or $\left.{ }^{76} \mathrm{Br}\right)$, incorporation of the isotope into the tracer molecule, injection of the tracer, PET scanning, and finally, application of mathematical models to convert the image into quantitative estimates of the concentration of the receptor or neurochemical $(19,20)$. As newer ligands are being synthesized more and more receptors and neurotransmitters are becoming accessible to in-vivo measurement (21).

\section{SAFETY}

The radiation exposure from a PET scan is comparable that of other diagnostic procedures used in nuclear medicine, and therefore is easily defensible in patients who are receiving direct benefit from the investigation. The issue is more complex when these techniques are used in normal volunteers or in research studies where there is no direct benefit to the patient. The radiation exposure from a PET scan is determined by the nature of the tracer, the amount of radioactive material administered, route of administration, and the total number of scans. As a broad generaliza- 
tion, the exposure may vary from a fifth to nearly double of what the normal population receives from background radiation sources within a year. In keeping with this, most research centers limit the number of times a normal volunteer can participate in PET experiments and the number of scans a volunteer can undergo in a single study.

\section{PET STUDIES OF RELEVANGE TO CLINICAL PSYCHIATRY}

\section{Schizophrenia}

The most enduring PET finding in schizophrenia is that of frontal dysfunctionthe pioneering studies by Buchsbaum et al. reported "frontal hypometabolism" (22-25); a finding which has since been observed by most (26-28), though not all groups $(29,30)$. Cleghorn et al. (31), on the other hand, report a relative frontal hyper-metabolism. PET scans of patients have been compared to controls while both were undertaking a smooth-pursuit eye-tracking task $(32,33)$, and while performing tasks requiring sustained attention $(25,34,35)$; both representing tasks on which patients with schizophrenia typically show impaired performance. Task-based comparisons accentuate the resting-state differences between normals and patients in the frontal lobes $(25,32-35)$ suggesting that not only is there a frontal dysfunction at rest, but that the response of the frontal lobe to the task demands is also deficient in patients with schizophrenia (36-38). In addition to investigations of the frontal lobe, the role of the temporal lobe (24,39-41), parietal lobe (40,42), and hemispheric asymmetry have been evaluated using PET $(43,44)$ though the PET evidence for impairment in these regions is less convergent (45).

Studies have sought to correlate clinical symptoms to regional brain abnormalities $(27,46)$. It appears that the onset of symptoms may be associated with frontal hyper-function (31), while with chronicity of symptoms and neuroleptic treatment the picture may change to one of frontal hypometabolism (27,31,32). Cleghorn and colleagues (47) compared patients who were actively hallucinating to those who were not and found that patients with active hallucinations had significantly lower metabolism in the auditory and Wernicke's area and a higher metabolism in Broca's area. Liddle and colleagues $(48,49)$ report a correlation between psychomotor poverty and left dorso-lateral prefrontal cortex abnormalities, conceptual disorganization and anterior cingulate region abnormalities, and hallucinations and delusions and medial temporal cortex abnormality. Relating phenomenology to abnormalities in discrete brain systems raises the possibility of a brain-based understanding of the different syndromes and sub-syndromes of this complex illness.

The dopamine hypothesis of schizophrenia is one of the most enduring neurochemical hypotheses of schizophrenia. However, dopamine receptor studies using PET have yielded conflicting findings (50). Wong and colleagues (51-53) reported a 2.5 -fold increase in the dopamine $\mathrm{D}_{2}$ receptors in the caudate-putamen of patients with schizophrenia using ${ }^{11} \mathrm{C}-\mathrm{N}$-methylspiperone as a ligand. In contrast, Farde $(54,55)$ and Heitala (18) using ${ }^{11} \mathrm{C}$-raclopride as a ligand, and Martinot (56) using 
${ }^{76} \mathrm{Br}$-bromolisuride, failed to find this increase. Differences in patient selection, differences in ligand characteristics, and differences in the mathematical modeling of the data have been suggested as possible causes for the observed differences in results (57). Studies with newer ligands will be required before the issue of $D_{2}$ dopamine receptors in schizophrenia is conclusively resolved $(52,55,58)$.

There is greater convergence, on the other hand, among studies investigating the relationship between $D_{2}$ receptor binding and neuroleptic treatment. The percent occupancy of the dopamine receptors in the striatum is closely related to plasma neuroleptic levels, though changes in receptor occupancy lag behind the changes in plasma levels (59-61). At the usual clinical dose, typical neuroleptics occupy $70 \%-85 \%$ of the available $\mathrm{D}_{2}$ receptors, an effect that is achieved, in most cases, at doses equivalent to about $150 \mathrm{mg}$ of chlorpromazine (62-66). The atypical neuroleptic clozapine, on the other hand, shows a lower occupancy of $\mathrm{D}_{2}$ receptors $(30-50 \%)$ and a higher occupancy of $\mathrm{D}_{1}$ and possibly $\mathrm{S}_{2}$ receptors (62-67). Receptor occupancy, beyond a certain threshold, does not seem to increase therapeutic effects but does tend to increase the level of extrapyramidal side-effects (68-71). Taken together the evidence suggests that with typical neuroleptics, a certain level of $\mathrm{D}_{2}$ receptor occupancy ( $70 \%$ or greater) is necessary, but may not be sufficient for a therapeutic effect. In addition to blocking the receptors, neuroleptics increase metabolism in the caudate-putamen $(30,40,72-75)$. At present the relevance of this finding is not clear. However, as the role of the striatum in cognition is unraveled further, it may become possible to understand the mechanism of neuroleptic medications in terms of their neuromodulatory effect on the striatum (75).

These initial studies in schizophrenia have offered promising leads. First, there is strong evidence for frontal dysfunction in schizophrenia, both at rest and while engaged in specific tasks; other cortical and subcortical regions may also be involved. Second, groups of symptoms can be related to a dysfunction of specific brain regions. Third, neuroleptic drugs produce significant changes in brain metabolism in the striatum via the occupancy of dopamine receptors. Fourth, a high level of dopamine $\mathrm{D}_{2}$ receptor occupancy is necessary for clinical response, but is not sufficient by itself. Fifth, the differences in the clinical profile of typical versus atypical neuroleptics may be related to the differences in the occupancy of the $\mathrm{D}_{2}$ and $\mathrm{D}_{1}$ and possibly $\mathrm{S}_{2}$ receptors. These findings are preliminary, but they offer the hope of developing a comprehensive understanding of the pathophysiology of schizophrenia and a rational approach to its treatment.

\section{Affective Disorders}

PET has made possible the study of the neuroanatomical pathways modulating mood. Pardo and colleagues have reported the involvement of the inferior frontal cortex in self-induced dysphoria in normal subjects (1). In patients, depressive symptoms are associated with a hypo-perfusion and hypo-metabolism in the prefrontal cortex $(6,76-80)$. It is unclear if this defect is similar to that seen in schizophrenia (81); it has recently been suggested that prefrontal hypo-metabolism may reflect 
psychomotor poverty, and that this may be the reason for prefrontal hypometabolism being observed in both schizophrenia and depression (82). Prefrontal cortex hypo-metabolism seems to be correlated with symptom severity and a resolution of clinical symptoms is accompanied with a trend towards normalization of this defect $(78,83,84)$. In addition to the frontal hypo-metabolism, studies have reported an involvement of the caudate-putamen (85) as well as limbic structures in depression $(6,80)$.

Previous studies investigating the neurochemical changes accompanying depression had to infer changes in the brain via peripheral measures such as receptors on peripheral cells or the neurotransmitter metabolites measured in the cerebrospinal fluid, plasma and urine. PET makes possible direct, in-vivo measures. Kishimoto and colleagues (86), using radiolabelled amino acids, reported a significant decrease in the amino acid pool in patients with depression and a significant increase in patients with mania. Agren and colleagues (87) reported a decreased transportation of ${ }^{11} \mathrm{C}-\mathrm{L}-5$-hydroxytryptophan across the blood-brain barrier in patients with depression. Using ${ }^{11} \mathrm{C}-\mathrm{N}$-methylspiperone ( $\left.{ }^{11} \mathrm{C}-\mathrm{NMSP}\right)$; a ligand which binds to the dopamine $\mathrm{D}_{2}$ and serotonin $\mathrm{S}_{2}$ receptors (88), Mayberg and colleagues (89) report that after unilateral strokes, ${ }^{11} \mathrm{C}-\mathrm{NMSP}$ binding negatively correlated with the degree of depressive symptoms. This suggests that a decrease in serotonin $\mathrm{S}_{2}$ receptor number or an inability to up-regulate $\mathrm{S}_{2}$ receptors in the ipsilateral hemisphere after a stroke may be associated with the symptoms of depression.

Thus, metabolic PET studies in depression implicate the prefrontal cortex, the caudate-putamen, and limbic structures as candidate structures subserving mood $(1,6,80)$. These findings help explain, at least in part, the increased propensity for developing depression secondary to stroke involving the frontal cortex, Parkinson's disease and Huntington's disease. The neurochemical and neuroreceptor studies using PET in depression have demonstrated the potential of in-vivo study, but there are few convergent or replicated findings. What is needed now are systematic studies which on the one hand identify the neuronal and neurochemical correlates of depressive symptoms, and on the other hand delineate the neurochemical effects of antidepressants which are crucial for the resolution of mood symptoms.

\section{Obsessive Compulsive Disorder (OCD)}

In a series of pioneering studies Baxter and colleagues described an elevation of metabolism in the right orbital gyrus and the caudate nucleus in OCD $(90,91)$. Subsequent studies by Baxter and colleagues and by other groups with more carefully selected drug-free non-depressed OCD patients confirmed this finding (90-93). Clinical improvement, whether due to pharmacological treatment (fluoxetine and clomipramine) or behavior therapy is associated with a normalization of the striatal hyper-metabolism (93-95).

These findings suggest that symptoms in OCD result from the generation of self-sustaining, improperly inhibited, positive feedback loops of motor and cognitive activity in frontal-striatal/limbic-thalamic circuits (96). In a symptom induction 
study, Rauch and colleagues (97) scanned patients with OCD while in an asymptomatic state and subsequently while experiencing experimentally-induced obsessivecompulsive symptoms. The symptoms were associated with an increased rCBF in the frontal-striatal-limbic circuit providing support for the above described model (97). It is remarkable that with the advent of functional imaging, in-vivo evidence is now available to identify a neurobiological basis for an illness which until recently was considered a prototypical 'functional neurosis'. This does not suggest that psychodynamic principles are superfluous, but it does suggest that the dichotomy between functional and organic illnesses may no longer be tenable. In fact, psychodynamic and biological explanations may be two complimentary levels of abstraction with which to understand the symptoms of OCD. Each framework may offer unique insights and unique treatments.

\section{Anxiety Disorders}

Anxiety disorders are the most common of psychiatric disorders, and yet little is known about the neuroanatomical basis of anxiety (98). Initial PET studies of patients with panic disorder suggested that at least a subset of them showed metabolic asymmetry in the hippocampal region (99). To test this hypothesis, Reiman and colleagues (100-102) induced panic attacks in susceptible subjects during the PET scan itself and found significant increases in the rCBF in the temporal poles, insular cortex, claustrum and putamen. However, these findings have subsequently been questioned and other groups fail to find the same results (103).

\section{Dementias}

Although no pathognomonic pattern of brain dysfunction diagnostic of dementia has emerged, patients with Alzheimer's disease do show a relative reduction in metabolism in the frontal and temporo-parietal association areas when compared to age-matched controls. There also seems to be an inverse correlation between overall symptoms and regional metabolism (104). In addition, there seems to be a significant loss in the serotonergic receptors in frontal and temporo-parietal cortical regions (105). The effects of the dementing illness are hard to distinguish since they are confounded by the effects of normal aging on metabolism $(106,107)$, receptors (88), and structural atrophy. While at this time the clinical utility is limited, it is hoped that with the application of advanced statistical methods (108) and cognitivechallenge techniques (109) PET could play an important role in the early diagnosis of dementia $(108,110)$, in differentiating Alzheimer's disease from multi-infarct dementia (111-113), and in distinguishing dementia from depression (114) and other confounding illnesses (111). 


\section{PET AND OTHER IMAGING MODALITIES}

PET provides the information about brain function. CT and the MRI techniques, on the other hand, provide the neuroanatomical information. The techniques complement each other, and by co-registering a MRI scan of a given individual to their PET scan the anatomical precision of the interpretations of the PET data may be improved (115). Recently, MRI scanners have been used to obtain information about regional changes in hemoglobin saturation; a technique which provides information similar to that obtained from PET rCBF studies (116-118). This technique of "functional MRI" is new, but once standardized, offers the potential of providing information regarding $\mathrm{rCBF}$ with greater anatomical precision and no radiation risk. Nuclear magnetic resonance spectroscopy uses magnetic resonance for measuring the level of neurochemical metabolites in different regions of the brain (119). The metabolites measured are different from those assessed using PET and therefore the two techniques can complement each other.

Single photon emission computed tomography or SPECT is an imaging modality which is functionally similar to PET. The major difference between the two is the nature of the tracer and the degree of spatial resolution. Tracers used in PET imaging involve short-lived isotopes of $\mathrm{C}, \mathrm{N}, \mathrm{O}$ and $\mathrm{F}$. While this permits the production of a wide variety of biological agents, it necessitates a cyclotron for the production of the tracers. SPECT imaging, on the other hand, incorporates long-lived isotopes of technetium and iodine. Since these elements do not naturally occur in a wide variety of biological chemicals, it limits the variety of compounds which can be produced, but since the half-life of the tracers is long, the tracers can be produced at a remote site and shipped to the camera-site for imaging. The present generation of PET cameras provide a higher degree of spatial resolution; however, with increasing sophistication in SPECT technology this difference in resolution is narrowing. Thus, PET imaging, due to the wider range of available ligands and higher resolution, may be more useful as a research tool in the initial stages of investigation. SPECT, due to its lower cost and greater availability, would be the vehicle for the wider dissemination of the useful research and clinical applications derived from initial PET studies.

\section{PET AND PSYCHIATRY-WHAT DOES THE FUTURE HOLD?}

The PET technology is undergoing continuous improvement; the in-plane resolution has reached the theoretical maximum of about $3 \mathrm{~mm}$. (3,5). PET and MRI images can be co-registered using automated software (120-122). Automated methods are now becoming available for image analysis (123-125). In addition, new statistical methods are being developed which will permit the comparison of brain networks rather than single regions (126-130).

It is now well recognized that dynamic tests, such as the cardiac stress test and the glucose tolerance test, are more sensitive and specific measures of the functional status of the respective physiological systems than baseline measures. Such ap- 
proaches should now be implemented in the field of psychiatry using PET. For example, rather than comparing schizophrenic patients with controls at rest, patients should be studied while engaged in cognitive tasks which best differentiate them behaviorally from their controls. Thereby, one would not only identify brain abnormalities, but more usefully, understand brain abnormalities which are specifically related to the functional deficits shown by the patients $(36,38)$. Mood states and anxiety levels can be modified experimentally in safe and ethical paradigms. Standardized "emotional challenges" should be developed and used with PET to delineate the neural networks which subserve mood $(1,2,97,102,103)$. Moreover, PET permits the in vivo study of the interaction of pharmacological, cognitive, and emotional states $(131,132)$. These approaches could be combined and the behavioral effects of drugs could be understood in terms of their neuroanatomically specific modulation of networks. Such studies may permit us to develop a comprehensive neurobiological framework of human emotion and behavior as a basis for understanding psychiatric illness (2).

The findings which will emerge using these new techniques and paradigms, in all likelihood, will not accommodate themselves in our present conceptual niches. Diagnostic systems, our ability to classify and categorize observable phenomenon, are the bedrock of scientific research and serve the purpose of identifying a relatively homogenous group of patients who can then be studied and with respect to whom predictions can be made. As opposed to the rest of modern medicine where nosology is primarily pathophysiology-based, the present system of classification in psychiatry is based on the identification of a cluster of symptoms. While such diagnostic systems have and may continue to serve us well clinically, this may not be the best way to identify homogenous groups of patients for neurobiological research. The real challenge then, will be to go beyond our current diagnostic constraints and look at the symptoms that cut across syndromes and syndromes that cut across disorders (82). For example, the same brain systems may subserve psychomotor poverty, irrespective of whether they are encountered in depression or schizophrenia. On the other hand, different brain systems may subserve psychomotor poverty and delusions/hallucinations even though these symptoms are clustered together under the diagnosis of schizophrenia (82). Thus, brain-based physiological systems, in addition to phenomenological clustering, may become the basis for diagnosing and treating psychiatric illness $(2,36,133)$. PET has opened the window to the brain-the next decade will determine if it will change our vision of mental illness.

\section{ACKNOWLEDGMENTS}

Dr. Shitij Kapur was supported by a Research Fellowship from the Ontario Mental Health Foundation. The authors would like to thank Dr. Robert Zipursky and Dr. Craig Hudson and Randi Rose for their constructive comments on this manuscript. 


\section{REFERENCES}

1. Pardo JV, Pardo PJ, Raichle ME: Neural correlates of self-induced dysphoria. Am J Psychiatry 1993; 150:713-719

2. Andreasen NC: Neural correlates of mental phenomena [editorial]. Am J Psychiatry 1993; 150:687-688

3. Phelps ME: Positron Emission Tomography (PET), in Clinical Brain Imaging: Principles and Applications. Edited by Mazziotta JC, Gilman S. Philadelphia, F. A. Davis Company, 1992

4. Volkow ND, Brodie J, Bendriem B: Positron emission tomography: basic principles and applications in psychiatric research. Ann NY Acad Sci 1991; 620:128-144

5. Bendriem B: Positron-Emission Tomography: From the Physics to the Instrument, in Positron-Emission Torography in Schizophrenia Research. Edited by Volkow ND, Wolf AP. Washington, American Psychiatric Press, Inc., 1991

6. Bench CJ, Friston KJ, Brown RG, et al: The anatomy of melancholia-focal abnormalities of cerebral blood flow in major depression. Psychol Med 1992; 22:607-615

7. Herscovitch P: Cerebral blood flow and metabolism measured with oxygen- 15 radiotracers. Journal of Neuropsychiatry and Clinical Neurosciences 1989; 1:S19-S29

8. Raichle ME, Martin WRW, Herscovitch P, et al: Brain blood flow measured with intravenous $\mathrm{H}_{2}{ }^{15} \mathrm{O}$. II. Implementation and validation. J Nucl Med 1983; 24:790-798

9. Posner MI, Petersen SE, Fox PR, et al: Localization of cognitive operations in the human brain. Science 1988; 240:1627-1631

10. Petersen SE, Fox PT, Posner MI, et al: Positron emission tomographic studies of the cortical anatomy of single-word processing. Nature 1988; 331:585-588

11. Frith CD, Friston KJ, Liddle PF, et al: Willed action and the prefrontal cortex in man: a study with PET. Proceedings of the Royal Society of London-Series B: Biological Sciences 1991; 244:241-246

12. Sokoloff L: Basic Principles in Imaging of Regional Cerebral Metabolic Rates, in Brain Imaging and Brain Function. Edited by Sokoloff L. New York, Raven Press, 1985

13. Petersen SE, Fox PT, Posner MI: Positron emission tomographic studies of the cortical anatomy of single-word processing. Nature 1988; 331:585-589

14. Doian RJ, Bench CJ, Friston K: Positron emission tomography in psychopharmacology. International Review of Psychiatry 1990; 2:427-439

15. Ponto LLB, Ponto JA: Uses and limitations of positron emission tomography in clinical pharmacokinetics/dynamics (Part II). Clin Pharmacokinet 1992; 22:273-283

16. Farde L, Halldin C, Stone-Elander S, et al: PET analysis of human dopamine receptor subtypes using 11C-SCH 23390 and 11C-Raclopride. Psychopharmacology 1987; 92:278284

17. Farde L, Wiesel FA, Hall H, et al: No D2 receptor increase in PET study of schizophrenia [letter]. Arch Gen Psychiatry 1987; 44:671-672

18. Hietala J, Syvälahti E, Klaus V, et al: Striatal D2 dopamine receptor characteristics in neuroleptic-naive schizophrenic patients studied with Positron Emission Tomography. Arch Gen Psychiatry 1994; 51:116-123

19. Wong DF, Gjedde A, Wagner HN Jr: Quantitation of neuroreceptors in the living brain. I. Irreversible binding of ligands. J Cereb Blood Flow Metab 1986; 6:137-146

20. Wong DF, Gjedde A, Wagner HN Jr, et al: Quantitation of neuroreceptors in the living brain. II. Inhibition studies of receptor density and affinity. J Cereb Blood Flow Metab $1986 ; 6: 147-153$ 
21. Stöcklin G: Tracers for metabolic imaging of brain and heart. Eur J Nucl Med 1992; 19:527-551

22. Buchsbaum MS: Cerebral glucography with positron tomography: Use in normal subjects and in patients with schizophrenia. Arch Gen Psychiatry 1982; 39:251-259

23. Buchsbaum MS, DeLisi LE, Holcomb HH: Anteroposterior gradients in cerebral glucose use in schizophrenia and affective disorders. Arch Gen Psychiatry 1984; 41:1159-1166

24. Buchsbaum MS: The frontal lobes, basal ganglia, and temporal lobes as sites for schizophrenia. Schizophrenia Bull 1990; 16:379-389

25. Buchsbaum MS, Nuechterlein KH, Haier RJ: Glucose metabolic rate in normals and schizophrenics during the Continuous Performance Test assessed by positron emission tomography. Br J Psychiatry 1990; 156:216-227

26. Cohen RM, Semple WE, Gross M: Dysfunction in a prefrontal substrate of sustained attention in schizophrenia. Life Sciences 1987; 40:2031-2039

27. Wolkin A, Sanfilipo M, Wolf AP, et al: Negative symptoms and hypofrontality in chronic schizophrenia. Arch Gen Psychiatry 1992; 49:959-965

28. DeLisi LE, Buchsbaum MS, Holcomb HH: Clinical correlates of decreased anteroposterior metabolic gradients in positron emission tomography (PET) of schizophrenic patients. Am J Psychiatry 1985; 142:78-81

29. Sheppard G, Gruzelier J, Manchanda R, et al: Positron emission tomographic scanning in predominantly never-treated acute schizophrenic patients. Lancet 1983; 1448-1452

30. Kling AS, Metter EJ, Riege WH, et al: Comparison of PET measurement of local brain glucose metabolism and CAT measurement of brain atrophy in chronic schizophrenia and depression. Am J Psychiatry 1986; 143:175-180

31. Cleghorn JM, Garnett ES, Nahmias C: Increased frontal and reduced parietal glucose metabolism in acute untreated schizophrenia. Psychiatry Research 1989; 28:1 19-133

32. Volkow ND, Wolf AP, Van Gelder P: Phenomenological correlates of metabolic activity in 18 patients with chronic schizophrenia. Am J Psychiatry 1987; 144:151-158

33. Volkow ND, Wolf AP, Brodie JD: Brain interactions in chronic schizophrenics under resting and activation conditions. Schizophr Res 1988; 1:47-53

34. Cohen RM, Semple WE, Gross M, et al: From syndrome to illness: delineating the pathophysiology of schizophrenia with PET. Schizophrenia Bull 1988; 14:169-176

35. Cohen RM, Semple WE, Gross M: The effect of neuroleptics on dysfunction in a prefrontal substrate of sustained attention in schizophrenia. Life Sciences 1988; 43:11411150

36. Wexler BW: Failure at task-specific regional brain activation: new conceptualization of a disease entity. Journal of Neuropsychiatry 1991; 3:94-98

37. Weinberger DR, Berman KF: Speculation on the meaning of cerebral metabolic hypofrontality in schizophrenia. Schizophrenia Bull 1988; 14:157-168

38. Berman KF, Illowsky BP, Weinberger DR: Physiological Dysfunction of Dorsolateral Prefrontal Cortex in Schizophrenia IV. Further Evidence for Regional and Behavioral Specificity. Arch Gen Psychiatry 1988; 45:616-622

39. Cleghorn JM, Garnett ES, Nahmias C, et al: Regional Brain Metabolism During Auditory Hallucinations in Chronic Schizophrenia. Br J Psychiatry 1990; 157:562-570

40. Szechtman H, Nahmias G, Garnett ES: Effect of neuroleptics on altered cerebral glucose metabolism in schizophrenia. Arch Gen Psychiatry 1988; 45:523-532

41. Volkow ND, Wolf AP, Van Gelder P, et al: Phenomenological correlates of metabolic activity in 18 patients with chronic schizophrenia. Am J Psychiatry 1987; 144:151-158 
42. Cleghorn JM, Garnett ES, Nahmias C, et al: Increased Frontal and Reduced Parietal Glucose Metabolism in Acute Untreated Schizophrenia. Psychiatry Research 1989; 28:119-133

43. Gur RE, Gur RC: Laterality in Schizophrenia: Positron-Emission Tomography Studies, in Positron-Emission Torography in Schizophrenia Research. Edited by Volkow ND, Wolf AP. Washington, American Psychiatric Press, Inc., 1991

44. Gur RE, Gur RC: Neurotransmitters are important, but so is metabolism. Neuropsychopharmacology 1992; 7:63-65

45. Cleghorn JM, Zipursky RB, List SJ: Structural and functional brain imaging in schizophrenia. Journal of Psychiatry \& Neuroscience 1991; 16:53-74

46. Volkow ND, Wolf AP (eds): Positron-Emission Tomography in Schizophrenia Research, Washington, American Psychiatric Press, Inc., 1991

47. Cleghorn JM, Franco S, Szechtman B, et al: Toward a brain map of auditory hallucinations. Am J Psychiatry 1992; 149:1062-1069

48. Liddle PF, Friston KJ, Frith CD, et al: Cerebral blood flow and mental processes in schizophrenia. J R Soc Med 1992; 85:224-227

49. Frith CD, Friston KJ, Liddle PF, et al: PET imaging and cognition in schizophrenia. J R Soc Med 1992; 85:222-224

50. Sedvall G: The current status of PET scanning with respect to schizophrenia. [Review]. Neuropsychopharmacology 1992; 7:41-54

51. Wong DF, Young LT: Strategies for in vivo quantification of human neuroreceptors by positron emission tomography. Neuropsychopharmacology 1990:386-399

52. Wong DF: PET studies of neuroreceptors in schizophrenia. Neuropsychopharmacology 1992; 7:69-72

53. Wong DF, Wagner HN, Tune LE: Positron emission tomography reveals elevated D-sub-2 dopamine receptors in drug-naive schizophrenics. Science 1986; 234:1558-1563

54. Farde L, Wiesel FA, Hall H: No D-sub-2 receptor increase in PET study of schizophrenia. Arch Gen Psychiatry 1987; 44:671-672

55. Sedvall G: Current status of PET scanning in schizophrenia. Neuropsychopharmacology 1992; 7:73-75

56. Martinot JL, Paillere-Martinot ML, Loc'h C: The estimated density of $\mathrm{D}_{2}$ striatal receptors in schizophrenia: A study with positron emission tomography and ${ }^{76} \mathrm{Br}$ bromolisuride. Br J Psychiatry 1991; 158:346-350

57. Andreasen NC, Carson R, Diksic M: Workshop on schizophrenia, PET, and dopamine D2 receptors in the human neostriatum. Schizophrenia Bull 1988; 14:471-484

58. Seeman P: Elevated $\mathrm{D}_{2}$ in schizophrenia: role of endogenous dopamine and cerebellumcommentary on "the current status of PET scanning with respect to schizophrenia." Neuropsychopharmacology 1992; 7:55-57

59. Cambon H, Baron JC, Boulenger JP, et al: Striatal dopamine receptors: Dose-dependent occupation by, and rapid washout of, orally given neuroleptics in humans, in Clinical Efficacy of Positron Emission Tomography. Edited by Heiss W-D, Pawlick G, Herholz K, et al. Dordrecht, Martinus Nijhoff Publishers, 1987

60. Smith M, Wolf AP, Brodie JD: Serial [18F]N-methylspiroperidol PET studies to measure changes in antipsychotic drug D-2 receptor occupancy in schizophrenic patients. Biol Psychiatry 1988; 23:653-663

61. Nordström Anna-L, Farde L, Wiesel Frits-A, et al: Central D2-Dopamine Receptor Occupancy in Relation to Antipsychotic Drug Effects: A Double-Blind PET Study of Schizophrenic Patients. Biol Psychiatry 1993; 33:227-235 
62. Farde L, Wiesel FA, Halldin C, et al: Central D2-dopamine receptor occupancy in schizophrenic patients treated with antipsychotic drugs. Arch Gen Psychiatry 1988; 45:71-76

63. Farde L, Nordström Anna-L, Wiesel Frits-A, et al: Positron emission tomographic analysis of central D1 and D2 dopamine receptor occupancy in patients treated with classical neuroleptics and clozapine. Arch Gen Psychiatry 1992; 49:538-544

64. Farde L, von Bahr C: Distribution of remoxipride to the human brain and central D2-dopamine receptor binding examined in vivo by PET. Acta Psychiatr Scand Suppl 1990; 358:67-71

65. Wiesel Frits-A, Farde L, Nordström Anna-L, et al: Central $\mathrm{D}_{1}$ - and $\mathrm{D}_{2}$-receptor occupancy during antipsychotic drug treatment. Prog Neuropsychopharmacol \& Biol Psychiat 1990; 14:759-767

66. Baron JC, Martinot JL, Cambon H: Targets for neurotransmitter receptor research using PET scan: the neuroleptic binding site. Psychopharmacol Ser 1989; 7:20-31

67. Seeman P: Receptor Selectivities of Atypical Neuroleptics, in Novel Antipsychotic Drugs. Edited by Meltzer HY. New York, Raven Press, 1992

68. Wolkin A, Barouche F, Wolf AP: Dopamine blockade and clinical response: evidence for two biological subgroups of schizophrenia. Am J Psychiatry 1989; 146:905-908

69. Farde L: Selective D1- and D2-dopamine receptor blockade both induces akathisia in humans - a PET study with [ ${ }^{11} \mathrm{CSCH} 23390$ and [ ${ }^{11} \mathrm{C}$ ] raclopride. 1992; 107:23-29

70. Farde L, Nordström Anna-L, Wiesel Frits-A, et al: Positron Emission Tomographic Analysis of Central $\mathrm{D}_{1}$ and $\mathrm{D}_{2}$ Dopamine Receptor Occupancy in Patients Treated With Classical Neuroleptics and Clozapine. Arch Gen Psychiatry 1992; 49:538-544

71. Baron JC, Martinot JL, Cambon H: Striatal dopamine receptor occupancy during and following withdrawal from neuroleptic treatment: correlative evaluation by positron emission tomography and plasma prolactin levels. 1989; 99:463-472

72. DeLisi LE, Holcomb HH, Cohen RM: Positron emission tomography in schizophrenic patients with and without neuroleptic medication. 1985; 5:201-206

73. Buchsbaum MS, Wu JC, DeLisi LE: Positron emission tomography studies of basal ganglia and somatosensory cortex neuroleptic drug effects: differences between normal controls and schizophrenic patients. Biol Psychiatry 1987; 22:479-494

74. Wolkin A, Jaeger J, Brodie JD, et al: Persistence of cerebral metabolic abnormalities in chronic schizophrenia as determined by positron emission tomography. Am J Psychiatry $1985 ; 142: 564-571$

75. Cleghorn JM, Szechtman H, Garnett ES: Neuroleptic effects on regional brain metabolism in first episode schizophrenics. Schizophr Res 1991; 5:208-209

76. Buchsbaum MS, Cappelletti J, Ball R, et al: Positron emission tomographic image measurement in schizophrenia and affective disorders. Ann Neurol 1984; 15 Suppl:S157_ S165

77. Baxter LR Jr, Phelps ME, Mazziotta JC: Cerebral metabolic rates for glucose in mood disorders. Studies with positron emission tomography and fluorodeoxyglucose F 18. Arch Gen Psychiatry 1985; 42:441-447

78. Baxter LR: PET studies of cerebral function in major depression and obsessivecompulsive disorder: The emerging prefrontal cortex consensus. Ann Clin Psychiatry 1991; 3:103-109

79. Martinot JL, Hardy P, Feline A: Left prefrontal glucose hypometabolism in the depressed state: A confirmation. Am J Psychiatry 1990; 147:1313-1317 
80. Drevets WC, Videen TO, Price JL, et al: A functional anatomical study of unipolar depression. J Neurosci 1992; 12:3628-3641

81. Cohen RM, Semple WE, Gross M, et al: Evidence for Common Alterations in Cerebral Glucose Metabolism in Major Affective Disorders and Schizophrenia. Neuropsychopharmacology 1989; 2:241-254

82. Dolan RJ, Bench CJ, Liddle PF, et al: Dorsolateral Prefrontal Cortex Dysfunction in the Major Psychoses—Symtpom or Disease Specificity. J Neurol Neurosurg Psychiatry 1993; 56:1290-1294

83. Baxter LR Jr, Schwartz JM, Phelps ME, et al: Reduction of prefrontal cortex glucose metabolism common to three types of depression. Arch Gen Psychiatry 1989; 46:243-250

84. Guze BH, Baxter LR, Szuba MP, et al: Positron-emission tomography and mood disorders, in Brain Imaging in Affective Disorders. Edited by Hauser P. Washington, DC, American Psychiatric Press, Inc., 1991

85. Hagman JO, Buchsbaum MS, Wu JC: Comparison of regional brain metabolism in bulimia nervosa and affective disorder assessed with positron emission tomography. $\mathrm{J}$ Affective Disord 1990; 19:153-162

86. Kishimoto H, Takazu O, Ohno S: 11C-glucose metabolism in manic and depressed patients. Psychiatry Research 1987; 22:81-88

87. Agren J, Reibring L, Hartvig P, et al: Low brain uptake of L- $\left[{ }^{11} \mathrm{C}\right] 5$-hydroxytryptophan in major depression: a positron emission tomography study on patients and healthy volunteers. Lancet 1991; 83:449-455

88. Wong DF, Wagner HN Jr, Dannals RF, et al: Effects of age on dopamine and serotonin receptors measured by positron tomography in the living brain. Science 1984; 226:13931396

89. Mayberg HS, Robinson RG, Wong DF: PET imaging of cortical S2 serotonin receptors after stroke: lateralized changes and relationship to depression. Am J Psychiatry 1988; 145:937-943

90. Baxter LR Jr, Phelps ME, Mazziotta JC, et al: Local cerebral glucose metabolic rates in obsessive-compulsive disorder. A comparison with rates in unipolar depression and in normal controls [published erratum appears in Arch Gen Psychiatry 1987 Sep;44(9):800]. Arch Gen Psychiatry 1987; 44:211-218

91. Baxter LR Jr, Schwartz JM, Mazziotta JC: Cerebral glucose metabolic rates in nondepressed patients with obsessive-compulsive disorder. Am J Psychiatry 1988; 145:1560 1563

92. Nordahl TE, Benkelfat C, Semple WE: Cerebral glucose metabolic rates in obsessive compulsive disorder. Neuropsychopharmacology 1989; 2:23-28

93. Benkelfat C, Hordahl TE, Semple WE, et al: Local Cerebral Glucose Metabolic Rates in Obsessive-Compulsive Disorder. Arch Gen Psychiatry 1990; 47:840-848

94. Swedo SE, Schapiro MB, Grady CL: Cerebral glucose metabolism in childhood-onset obsessive-compulsive disorder. Arch Gen Psychiatry 1989; 46:518-523

95. Azari NP, Swedo SE, Pietrini P, et al: Altered patterns of glucose metabolism (rCMRglc) after clomipramine treatment in obsessive-compulsive disorder (OCD). 1993; 13:S522

96. Baxter LRJr: Neuroimaging studies of obsessive compulsive disorder. [Review]. Psychiatr Clin North Am 1992; 15:871-884

97. Rauch SL, Jenike MA, Alpert NM, et al: Regional Cerebral Blood Flow Measured During Symptom Provocation in Obsessive-Compulsive Disorder Using Oxygen 15-Labeled Carbon Dioxide and Positron Emission Tomography. Arch Gen Psychiatry 1994; 51:62-70

98. Kuhar MJ: Neuroanatomical substrates of anxiety: A brief survey. TINS 1986; 9:307-311 
99. Reiman EM: A focal brain abnormality in panic disorder, a severe form of anxiety. Nature 1984; 310:683-685

100. Reiman EM, Raichle ME, Robins E, et al: The application of positron emission tomography to the study of panic disorder. Am J Psychiatry 1986; 143:469-477

101. Reiman EM: The study of panic disorder using positron emission tomography. Psychiatric Developments 1987; 5:63-78

102. Reiman EM, Raichle ME, Robins E: Neuroanatomical correlates of a lactate-induced anxiety attack. Arch Gen Psychiatry 1989; 46:493-500

103. Mountz JM, Modell JG, Wilson MW: Positron emission tomographic evaluation of cerebral blood flow during state anxiety in simple phobia. Arch Gen Psychiatry 1989; 46:501-504

104. Rapoport SI: Positron emission tomography in Alzheimer's disease in relation to disease pathogenesis: a critical review. Cerebrovascular \& Brain Metabolism Reviews 1991; 3:297-335

105. Blin J, Baron JC, Dubois B, et al: Loss of brain 5-HT2 receptors in Alzheimer's disease. In vivo assessment with positron emission tomography and [18F] setoperone. Brain 1993; 116:497-510

106. Riege WH, Metter EJ, Kuhl DE, et al: Brain glucose metabolism and memory functions: Age decrease in factor scores. J Gerontol 1985; 40:459-467

107. Rapoport SI, Duara R, Grady CL, et al: Cerebral Glucose Utilization in Relation to Age in Man, in The Metabolism of the Human Brain Studied with Positron Emission Tomography. Edited by Greitz T, Ingvar DH, Widén L. New York, Raven Press, 1985

108. Azari NP, Pettigrew KD, Schapiro MB, et al: Early Detection of Alzheimer's Disease: A Statistical Approach Using positron Emmission Tomographic Data. 1993; 13:438-447

109. Grady CL, Haxby JV, Horwitz B, et al: Activation of Cerebral Blood Flow During a Visuoperceptual Task in Patients with Alzheimer-Type Dementia. Neurobiol Aging 1993; 14:35-44

110. Grady CL, Haxby JV, Horwitz B: Longitudinal study of the early neuropsychological and cerebral metabolic changes in dementia of the Alzheimer type. J Clin Exp Neuropsychol 1988; 10:576-596

111. Heiss WD, Herholz K, Pawlik G, et al: Positron emission tomography findings in dementia disorders: contributions to differential diagnosis and objectivizing of therapeutic effects. Keio J Med 1989; 38:111-135

112. Brown WD, Frackowiak RS: Cerebral blood flow and metabolism studies in multi-infarct dementia. Alzheimer Dis Assoc Disord 1991; 5:131-143

113. Meguro K, Doi C, Ueda M: Decreased cerebral glucose metabolism associated with mental deterioration in multi-infarct dementia. Neuroradiology 1991; 33:305-309

114. Guze BH, Baxter LR Jr, Schwartz JM, et al: Changes in glucose metabolism in dementia of the Alzheimer type compared with depression: a preliminary report. Psychiatry Research 1991; 40:195-202

115. Resnick SM, Karp JS, Turetsky B, et al: Comparison of Anatomically-Defined Versus Physiologically-Based Regional Localization-Effects on Pet-Fdg Quantitation. J Nucl Med 1993; 34:2201-2207

116. Ellis SJ: Functional Magnetic Resonance-Neurological Enlightenment? Lancet 1993; 342:882

117. Connelly A, Jackson GD, Frackowiak RSJ, et al: Functional Mapping of Activated Human Primary Cortex with a Clinical MR Imaging System. Radiology 1993; 188:125-130 
118. Cohen JD, Noll DC, Schneider W: Functional Magnetic Resonance Imaging: Overview and Methods for Psychological Research. Behavior Research Methods, Instruments, \& Computers 1993:In Press

119. Keshavan MS, Kapur S, Pettegrew JW: Magnetic resonance spectroscopy in psychiatry: potential, pitfalls, and promise [published erratum appears in Am J Psychiatry 1992 Mar; 149(3):431]. Am J Psychiatry 1991; 148:976-985

120. Evans AC, Marrett S, Torrescorzo J, et al: MRI-PET Correlation in Three Dimensions Using a Volume-of-Interest (VOI) Atlas. 1991; 11:A69-A78

121. Woods RP, Cherry SR, Mazziotta JC: Rapid automated algorithm for aligning and reslicing PET images. J Comput Assist Tomogr 1992; 16:620-633

122. Steinmetz $\mathrm{H}$, Huang $\mathrm{Y}$, Seitz RJ, et al: Individual integration of positron emission tomography and high-resolution magnetic resonance imaging. 1992; 12:919-926

123. Mintun MA, Fox PT, Raichle ME: A highly accurate method of localizing regions of neuronal activation in the human brain with positron emission tomography. $\mathrm{J}$ Cereb Blood Flow Metab 1989; 9:96-103

124. Worsley KJ, Evans AC, Marrett S, et al: A three-dimensional statistical analysis for CBF activation studies in human brain. J Cereb Blood Flow Metab 1992; 12:900-918

125. Friston KJ, Frith CD, Liddle PF, et al: Comparing functional (PET) images: the assessment of significant change. J Cereb Blood Flow Metab 1991; 4:690-699

126. Friston KJ, Frith CD, Liddle PF, et al: Functional Connectivity: The PrincipalComponent Analysis of Large (PET) Data Sets. 1993; 13:5-14

127. Moeller JR, Strother SC: A regional covariance approach to the analysis of functional patterns in positron emission tomographic data. 1991; 11:A121-A135

128. Clark CM, Ammann W, Martin WR, et al: The FDG/PET methodology for early detection of disease onset: a statistical model. 1991; 11:96-102

129. Horwitz B: Functional interactions in the brain: use of correlations between regional metabolic rates. 1991; 11:A114-A120

130. McIntosh AR, Grady CL, Ungerleider LG, et al: Network Analysis of Cortical Visual Pathways Mapped with Pet. J Neurosci 1994; 14:655-666

131. Friston KJ, Grasby PM, Frith CD, et al: The neurotransmitter basis of cognition: psychopharmacological activation studies using positron emission tomography. Ciba Foundation Symposium 1991; 163:76-87

132. Friston KJ, Grasby PM, Bench CJ, et al: Measuring the neuromodulatory effects of drugs in man with positron emission tomography. Neurosci Lett 1992; 141:106-1 10

133. Parks RW, Crockett DJ, McGeer PL: Systems model of cortical organization: Positron emission tomography and neuropsychological test performance. Arch Clin Neuropsychol $1989 ; 4: 335-349$ 